\title{
Adansonian Analysis of the Rhizobiaceae
}

\author{
By MELDA L. MOFFETT* AND RITA R. COLWELL \\ Department of Biology, Georgetown University, Washington D.C. 20007, U.S.A.
}

(Accepted for publication 30 September 1967)

\begin{abstract}
SUMMARY
One hundred and ninety-one coded features of 2I strains of the genera Rhizobium, I 8 of Agrobacterium, I I of Chromobacterium, selected strains of Vibrio cholerae, Flavobacterium, and other representative strains of the families Enterobacteriaceae and Pseudomonadaceae were subjected to Adansonian analysis, with the use of a high-speed computer for the establishment of Similarity (S) and Matching (M) coefficients and for the sorting of the strains into taxonomic clusters. From the frequency of occurrence of features computed for each of the clusters, tables were prepared which provided correlated characteristics suitable for the description of the clusters. Hypothetical median organisms were also computed for each of the clusters and actual strains were selected as neotypes for the new genera, Rhizobium and Phytomyxa. The genus Rhizobium includes the fast-growing rhizobia and the agrobacteria and contains at least four species: $R$. meliloti, $R$. leguminosarum, $R$. radiobacter, $R$. rubi. The genus Phytomyxa is reserved for the slowgrowing rhizobia which have been placed in the species $R$. japonicum. Agrobacterium gypsophilae and $A$. pseudotsugae are removed from both Rhizobium and Phytomyxa as defined in this study. The lack of significantly high intergeneric relationships amongst the members of the family Rhizobiaceae suggest revaluation of the family structure. From the results obtained here, the genera Rhizobium and Phytomyxa appear more closely related to the members of the Pseudomonadaceae.
\end{abstract}

\section{INTRODUCTION}

Bacterial taxonomy is at present experiencing a renewal of interest due mainly to developments in information science, molecular biochemistry and molecular genetics. Relationships amongst the soil bacteria as presented in the seven editions of Bergey's Manual of Determinative Bacteriology were based primarily on brilliant deductions and the intuitive genius of the pioneer bacteriologists such as Winogradsky, Beijerinck and others.

The soil bacteria received a good deal of attention in the earliest days of bacteriology and the taxonomy of the root nodule bacteria traces to the papers of Schroeter (I886) who separated the root nodule bacteria into two species which were based entirely on root nodule structure. Beijerinck (1888) described the isolation and distinct morphological forms of Phytomyxa leguminosarum and Phytomyxa lupini, the two species established by Schroeter. The root nodule bacteria have been grouped on characteristic legume root nodulation and subgrouped on the range and type of host plants infected. Bergey's Manual (1957) accords six of the subgroups (Rhizobium

* Present address: Queensland Department of Primary Industries, William Street, Brisbane, Queensland, Australia. 
leguminosarum Frank, $R$. trifolii Dangeard, R.phaseoli Dangeard, R. meliloti Dangeard, $R$. japonicum Kirchner, $R$. lupini Schroeter) specific status. This classification, however, has not fully held up to the tests of time and of new methodologies (Lange, I96I; Graham, I964; De Ley \& Rassel, 1965). Furthermore, the generic relationships within the Rhizobiaceae, i.e. intergeneric relationships of Rhizobium, Agrobacterium and Chromobacterium, as well as the intrageneric relationships require some careful reconsideration (Lange, I96r). The DNA homology studies of De Ley, Bernaerts, Rassel \& Guilmot (I966a) also indicate the need for re-evaluation of the family Rhizobiaceae.

An evaluation of certain diagnostic features currently used in identification and classification of Rhizobium species was presented by Graham \& Parker (1964) and an Adansonian analysis of Chromobacterium species was made by Sneath (I957), who provided an extended description for that genus. However, no comparative and complete descriptions of the genera of the Rhizobiaceae are available at the present time.

The study reported here is an Adansonian analysis of the Rhizobiaceae and is intended as an extended survey of the in vitro features used in the diagnosis of these bacteria. The relationships amongst the strains representing the genera Rhizobium, Agrobacterium, Chromobacterium, Pseudomonas, Enterobacter, Escherichia, Vibrio and Proteus have been examined on the basis of all available evidence, i.e. computed similarities, nucleic acid data and enzymic similarities. The frequencies of occurrence of each of the characters tested in the present analysis provide an extended description of the species within the family Rhizobiaceae as well as patterns of characters useful in diagnostic applications.

\section{METHODS}

\section{Organisms}

A total of 59 cultures was used in the study. The species represented and the source of isolates are listed in Table I. The Rhizobium and Agrobacterium strains, with the exception of isolates 6466 and 5GLY.FE, were maintained on a modification of the basal medium described by Graham \& Parker (1964): (in g./1.) $\mathrm{MgSO}_{4} \cdot{ }_{7} \mathrm{H}_{2} \mathrm{O}$, $0.25 ; \mathrm{CaSO}_{4} .2 \mathrm{H}_{2} \mathrm{O}, 0.03 ; \mathrm{Na}_{2} \mathrm{HPO}_{4} . \mathrm{I}_{2} \mathrm{H}_{2} \mathrm{O}, \mathrm{I} \cdot 20 ; \mathrm{KH}_{2} \mathrm{PO}_{4}, 0.55 ; \mathrm{NaCl}, 0.25$; $\mathrm{FeSO}_{4} \cdot 7 \mathrm{H}_{2} \mathrm{O}, 0.0035 ; \mathrm{ZnSO}_{4} \cdot 7 \mathrm{H}_{2} \mathrm{O}$, 0.000I6; $\mathrm{CuSO}_{4} .5 \mathrm{H}_{2} \mathrm{O}, 0.00008 ; \mathrm{H}_{3} \mathrm{BO}_{3}$, $0.0005 ; \mathrm{MnSO}_{4} .4 \mathrm{H}_{2} \mathrm{O}$, 0.0004; Difco yeast extract, 0.25; Bacto agar, 20.0; mannitol, Io; $\mathrm{pH} 7 \cdot 0$. This medium (YM) with the addition of $\mathrm{I} \%$ proteose peptone (YMP) was used for the maintenance of the remaining isolates included in the study. Each strain was examined for purity before testing was begun. Furthermore, before inoculation of each test medium, all cultures were streaked out to confirm purity. In addition to the strains listed in Table I, 26 strains, including the genera Pseudomonas, Serratia, Alcaligenes, Flavobacterium and Xanthomonas, for which coded data from previous studies were in storage on the computer, were compared by retrieving their data.

\section{Characters and methods of testing}

A total of 19I characters were studied and coded for computer analysis. These are listed in the text which follows by character sequence number from the computer analysis (numbers in parentheses). The media for examination of physiological features was prepared by using a salts diluent (Graham \& Parker 1964); however, the 
Table I. Source of isolates included in the computer analysis

\begin{tabular}{|c|c|c|}
\hline Strain no. & Culture & Source \\
\hline $922^{*}$ & Rhizobium sp. & $\begin{array}{l}\text { Glycine javanica. M. M. Kennedy, Ayr, Queens- } \\
\text { land, Australia }\end{array}$ \\
\hline $942^{*}$ & Rhizobium sp. & $\begin{array}{l}\text { Phaseolus aureus CB } 5 \text { I2 D. O. Norris, Taroom, } \\
\text { Queensland, Australia }\end{array}$ \\
\hline $\begin{array}{l}948^{*} \\
95^{*}\end{array}$ & $\begin{array}{l}\text { Rhizobium sp. } \\
\text { R. japonicum }\end{array}$ & $\begin{array}{l}\text { Phaseolus aureus } \mathrm{CB} \text { I2I D. O. Norris, Australia } \\
\text { Glycine max } \mathrm{CB} 1003 \text { D. O. Norris, Thailand }\end{array}$ \\
\hline $\begin{array}{l}952 \\
963^{*}\end{array}$ & Rhizobium sp. & Lotononis bainesii CB $376 \mathrm{D}$. O. Norris, Australia \\
\hline $965^{*}$ & Rhizobium sp. & Arachis prostrata $\mathrm{CB} 530$ D. O. Norris, Australia \\
\hline 988 & Rhizobium sp. & Leucaena glauca NGR 8 ex Trinnick, New Guinea \\
\hline $9897^{*}$ & $\begin{array}{l}\text { Rhizobium sp. } \\
\text { Rhizobium sp. }\end{array}$ & $\begin{array}{l}\text { Clitoria ternatea СВ } 930 \text { D. O. Norris, Australia } \\
\text { Dolichos africanus CB } 756 \text { D. O. Norris, }\end{array}$ \\
\hline $998^{*}$ & Rhizobium sp. & $\begin{array}{l}\text { Marandellos, South Rhodesia } \\
\text { Desmodium intortum CB } 627 \text { D. O. Norris, Ex } \\
\text { Bonnier, Congo }\end{array}$ \\
\hline WU $425 \dagger$ & Rhizobium sp. & $\begin{array}{l}\text { Ornithopus compressus strain s } 3 \text { (M. D. Brocx), } \\
\text { Esperance, Western Australia (effective on } \\
\text { lupins and Ornithopus) }\end{array}$ \\
\hline 10317 & Rhizobium sp. & ATCC \\
\hline WU 7 & R. lupini & $\begin{array}{l}\text { D 27, Swanbourne, Western Australia (isolated } \\
\text { by Dr R. T. Lange) authentic } 1960\end{array}$ \\
\hline 10318 & R. lupini & ATCC \\
\hline SU2I6: & R. meliloti & $\begin{array}{l}\text { Medicago sativa strain } 107 \text { S.C.w.-5. Wisconsin, } \\
\text { U.S.A. (Parker) }\end{array}$ \\
\hline SU 277 & R. meliloti & $\begin{array}{l}\text { Medicago tribuloides. M. Tr. Perth, Western } \\
\text { Australia (seed from Perth but nodulated } \\
\text { plant from Leeton Exp. Farm as } 27 \mathbf{I}-279 \text { ) }\end{array}$ \\
\hline SU 298 & R. trifolii & $\begin{array}{l}\text { Isolated from effective plant of Crimson } \\
\text { Clover } 1174 \mathrm{~A} / 2\end{array}$ \\
\hline SU 299 & R. leguminosarum & $\begin{array}{l}\text { Vetch and pea culture, New South Wales } \\
\text { Department of Agriculture, Australia } \\
\text { (originally from U.S.A.) }\end{array}$ \\
\hline sU30I & R. leguminosarum & $\begin{array}{l}\text { Pea B-isolated from effective Field Pea } \\
\text { Dunoon, } 195^{2}\end{array}$ \\
\hline SU 308 & R. trifolii & $\begin{array}{l}\text { A.G. I4 K. J. Baird, Armidale, New South Wales, } \\
\text { Australia }\end{array}$ \\
\hline SU 312 & R.phaseoli & $\begin{array}{l}\text { Bean culture, New South Wales Department of } \\
\text { Agriculture (I955 Reclassified Nal), Australia }\end{array}$ \\
\hline 4720 & $\begin{array}{l}\text { Agrobacterium } \\
\text { tumefaciens }\end{array}$ & $\begin{array}{l}\text { American Type Culture Collection (ATCC) } \\
\text { Washington, D.C. }\end{array}$ \\
\hline III56 & A. tumefaciens & ATCC \\
\hline 11157 & A. tumefaciens & ATCC \\
\hline B 6 & A. tumefaciens & $\begin{array}{l}\text { P. K. Chen, Georgetown University, Wash., D.C. } \\
\text { (highly virulent strain) }\end{array}$ \\
\hline A 6 RI & A. tumefaciens & $\begin{array}{l}\text { P. K. Chen, Georgetown University, Washington } \\
\text { D.C. (virulent strain) }\end{array}$ \\
\hline A 66 RI & A. tumefaciens & $\begin{array}{l}\text { P. K. Chen, Georgetown University, Washington } \\
\text { D.C. (attenuated strain) }\end{array}$ \\
\hline $5 \mathrm{GLY} . \mathrm{FE}$ & A. tumefaciens & $\begin{array}{l}\text { P. K. Chen, Georgetown University, Washington } \\
\text { D.C. (avirulent strain) }\end{array}$ \\
\hline 4718 & A. radiobacter & ATCC \\
\hline $\begin{array}{l}6466 \\
\text { A. RADIO. }\end{array}$ & A. radio & 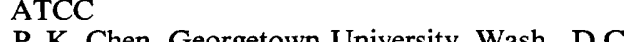 \\
\hline $\begin{array}{l}\text { A. RADIO. } \\
\text { AR IOOI }\end{array}$ & $\begin{array}{l}\text { A. radiobacter } \\
\text { A. radiobacter }\end{array}$ & $\begin{array}{l}\text { P. K. Chen, Georgetown University, Wash., D.C. } \\
\text { P. K. Chen, Georgetown University, Wash., D.C. }\end{array}$ \\
\hline AR 1012 & A. radiobacter & P. K. Chen, Georgetown University, Wash., D.C. \\
\hline I1325 & A. rhizogenes & ATCC \\
\hline I 3333 & A. rhizogenes & ATCC \\
\hline $\begin{array}{l}13334 \\
13335\end{array}$ & $\begin{array}{l}\text { A. rubi } \\
\text { A. rubi }\end{array}$ & $\begin{array}{l}\text { ATCC } \\
\text { ATCC }\end{array}$ \\
\hline 13335 & A. rubi & ATCC \\
\hline
\end{tabular}


Table 1 (cont.)

Strain no.

$\begin{array}{ll}13330 & \text { A. pseudotsugae } \\ 13331 & \text { A. pseudotsugae } \\ 13329 & \text { A. gypsophilae } \\ 12472 & \text { Chromobacterium } \\ \text { violaceum } \\ 6357 & \text { C. violaceum } \\ 12540 & \text { C. violaceum } \\ 12541 & \text { C. violaceum } \\ 12542 & \text { C. violaceum } \\ 553 & \text { C. violaceum } \\ 13426 & \text { C. violaceum } \\ 6918 & \text { C. viscosum } \\ 12473 & \text { C. lividum } \\ 6915 & \text { C. amethystinum } \\ 16266 & \text { Pseudomonas fluores- } \\ & \text { cens var. antirrhi- } \\ & \text { nastri } \\ 13430 & \text { P. fluorescens } \\ 14216 & \text { P. aeruginosa } \\ \text { I4033 } & \text { Vibrio cholerae } \\ \text { W I485 } & \text { Escherichia coli } \mathrm{K} \text { I2 } \\ & \text { Enterobacter } \\ 4115 & \text { aerogenes } \\ 9247 \mathrm{TR} & \text { Proteus morganii } \\ \text { PM-I } & \text { Proteus mirabilis } \\ & \text { Providence } \text { sp. }\end{array}$

ATCC

ATCC

ATCC

ATCC

ATCC

ATCC

ATCC

ATCC

ATCC

ATCC

ATCC

ATCC

ATCC

Pathogenic on antirrhinum seedlings; Queensland, Australia

ATCC

ATCC

ATCC

S. Falkow, Walter Reed Army Institute of

Research, Washington D.C.

S. Falkow, Walter Reed Army Institute of

Research, Washington, D.C.

S. Falkow, Walter Reed Army Institute of Research, Washington, D.C.

S. Falkow, Walter Reed Army Institute of Research, Washington, D.C.

S. Falkow, Walter Reed Army Institute of Research, Washington, D.C.

* Strain numbers refer to strains obtained from A. Diatloff, Queensland Department of Primary Industries.

$\dagger$ WU strain numbers refer to strains obtained from Dr C. A. Parker, University of Western Australia.

‡ SU strains received from Dr P. H. Graham, University of Sydney.

media of Simmons and Paton (see below) were made up with distilled water. All tests were read at I, 2, 7 days and 2, 3, and 4 weeks except for nutritional requirements which were read after 7 days and discarded. Plate inoculations were made by the spot drop (Colwell, 1964) or replica plate technique (Lederberg, 1950). Liquid media were inoculated with 2 drops from a Pasteur pipette of a 3-day culture or, in the case of the slow-growing organisms, 5-day culture.

Morphological characters (I-I5) were scored from cultures grown at $25^{\circ}$ on agar after 2 days (fast-growing isolates) and 5 days (slow-growing isolates), and examined by phase-contrast microscopy. The characters scored included: rods; curved rods; (oval) spheres; presence of filaments; refractile appearance of organisms; distribution of organisms as predominantly singles, pairs or chains; round or tapered ends; spirals (rods); length $\mathrm{I}-3 \mu$ or $3-5 \mu$; and width $0.6-\mathrm{I} \cdot 0 \mu$ or $0 \cdot 2-0.6 \mu$.

Motility (I6) was scored from wet mount preparations examined under phasecontrast microscopy. Examination of broth cultures for motility was done at the same time as the growth characteristics in liquid media were scored (see below).

Flagella stains (I7-18) of smears from YM agar slants (Rhizobium species) and 
nutrient agar (remaining isolates) were used to distinguish polar from peritrichous flagellar arrangements (Leifson, I95I).

The Gram stain (19-2I) used was the Hucker modification (Society of American Bacteriologists, 1957) and cultures were scored as Gram negative, positive, or variable.

Colonial characteristics (22-34) were determined on YM and YMP agar at 3 days and also at 5-10 days for the Rhizobium species. The characters included: small colony size (I-2 mm.); medium colony size (2-5 mm.); convex; rough; opaque; translucent; entire edge, spreading on agar surface; white colony colour; off white colony colour; grey colony colour; butyrous consistency; gum production; mucilaginous colony.

Presence or absence of capsules (35) was determined by using indian ink (Bradshaw, 1964) and metachromatic granules (36) with methylene blue (Bradshaw, 1964).

Pigment production (37-40), as a diffusible green pigment, diffusible blue pigment, or visible insoluble pigment, was scored from examination of YM agar, YMP agar, Pseudomonas agar F (Difco), and Pseudomonas agar P (Difco). Fluorescence was determined in a liquid medium (Paton, 1959).

Growth characteristics in liquid media (4I-47) included: presence of pellicle or ring; granular or even turbidity; slight, moderate or heavy turbidity with Brown's opacity tubes as reference. Characteristics in liquid media were determined for all isolates in YM broth at 2 and at 5 days, as well as in YMP broth for those isolates which preferentially in a medium with an organic nitrogen source.

Carbohydrate metabolism (48-89). Oxidative and fermentative utilization of carbohydrates was determined by the method of Hugh \& Leifson (I953). This medium, without agar and with an inverted inner vial, was also used to detect gas production from carbohydrates. Growth in glucose with and without $\mathrm{IO}^{-3} \mathrm{M}$-iodoacetate was determined. The terminal $\mathrm{pH}$ value in the glucose fermentation tubes was also measured. Growth and production of acetic acid in ethanol agar was recorded (Shimwell, Carr \& Rhodes, 1960). Acid production from carbohydrates (I \%,w/v) and ethanol (5\%, w/v) was determined on agar plates, with the peptone omitted for Rhizobium and Agrobacterium species. The carbohydrates were sterilized by filtration except dulcitol, inulin and dextrin which were steamed for $\mathrm{I} \mathrm{hr}$ on three successive days. The carbohydrates which were tested were : glucose, maltose, lactose, sucrose, galactose, mannitol, adonitol, arabinose, cellobiose, dextrin, dulcitol, fructose, glycerol, inositol, inulin, mannose, melibiose, melezitose, raffinose, rhamnose, salicin, sorbitol, trehalose, xylose, ethanol. Hydrolysis of aesculin and starch, production of dihydroxyacetone from glycerol, and digestion of agar were tested by the methods cited by Colwell (1964). Examination for levan production on YM and YMP agar by the Graham \& Parker (1964) modification of the Paton (I960) technique was also done.

The methyl red and Voges-Proskauer tests (90-91) were performed following the techniques described in the Manual of Microbiological Methods (1957).

Temperature range of growth (92-102) was determined in YM and YMP broth. Before inoculation for temperature growth tests, the medium was incubated at the given test temperature overnight. Temperatures studied were: $0,5,15,20,30,35,37$, $40,4 \mathrm{I}, 42$ and $44^{\circ}$.

$\mathrm{NaCl}$ tolerance (103-I08) was tested on YM and YMP agar plates (Ionagar, Difco Labs, Chicago, Illinois) adjusted to the required $\mathrm{NaCl}$ concentrations: $0,0.5,3 \cdot 0$, $5 \cdot 0,7 \cdot 0,10.0 \%(\mathrm{w} / \mathrm{v})$. 
The $\mathrm{pH}$ range of growth (109-1 16) was determined in YM and YMP broth adjusted to the required $\mathrm{pH}$ values before autoclaving, but in the case of $\mathrm{pH} 44^{\circ}, 4 \cdot 5,5^{\circ}, 9^{\circ} 0$ and 10.0 the media were readjusted and dispensed aseptically after autoclaving. The $\mathrm{pH}$ values tested included: $4 \cdot 0,4 \cdot 5,55^{\circ}, 6 \cdot 0,7 \cdot 0,8 \cdot 0,9 \cdot 0$ and $0^{\circ} \cdot 0$.

The oxidase, cytochrome oxidase, and catalase tests (II7-I I9) were made by the methods cited by Colwell (1964).

The production of phosphatase (120) was detected on YM and YMP agar by the method of Baird-Parker (1963).

Sensitivity to antibiotics and antibacterials (12I-I33). Sensitivity to the $0 / 129$ pteridine compound was tested following the method of Shewan, Hodgkiss \& Liston (1954). Antibiotic sensitivities were determined by using BBL (Baltimore Biological Laboratories, Baltimore, Md.) 'Sensidiscs'. Resistance to concentrations of $\mathbf{H g C l}_{\mathbf{2}}$ was determined by incorporation of the compound in agar media. YM and YMP agar was used in all instances where sensitivities to antibiotics and antibacterials were tested. The substances and concentrations (per ml.) used were: penicillin, Io units; dihydrostreptomycin, Io $\mu \mathrm{g}$; chloromycetin, $30 \mu \mathrm{g}$; erythromycin, $15 \mu \mathrm{g}$.; kanamycin, $30 \mu \mathrm{g}$.; aureomycin, $30 \mu \mathrm{g}$.; novobiocin, $30 \mu \mathrm{g}$.; polymyxin $\mathrm{B}, 300$ units; terramycin, $30 \mu \mathrm{g}$.; tetracycline, $30 \mu \mathrm{g}$.; $\mathrm{HgCl}_{2}$, I $\mu \mathrm{g}$ and $10 \mu \mathrm{g}$.

Reduction of nitrate and nitrite, gelatin liquefaction and litmus milk tests (134-143) were made following the technique of the Manual of Microbiological Methods (I957) and scored as described by Colwell (I964).

Growth on skim milk agar and casein hydrolysis (144-I45) were determined with the skim milk agar medium of Gordon \& Mihm (1959).

Production of ammonia from peptone at 14 days and hydrogen sulphide from peptone in lead acetate agar (146-I47) was measured following the techniques described in the Manual of Microbiological Methods (1957). Hydrogen sulphide production from cystine and cysteine (148-149) was determined in micro-tubes with lead acetate paper (Colwell \& Quadling, 1962).

Urease production (I50) was tested according to the method of Christensen (I946) with peptone omitted from the media for the Rhizobium and Agrobacterium species.

Indole production (15I) was tested by the Kovacs modification cited in the Manual of Microbiological Methods (1957).

Lecithinase (152) production was tested on YM and YMP agar plates in which $5 \%$ (v/v) concentrated egg-yolk emulsion (Oxoid, Colab, Inc., Chicago, Illinois) was incorporated.

Lipolytic activity (153-I56) was determined by detection of hydrolysis of Tweens 20 , 40, 60 and 80, respectively, in YM and YMP agar following the method of Sierra (1957).

The production of 3-ketolactose (157) was determined by the method of Bernaerts \& De Ley (1963).

Ability to utilize citrate (158-159) was determined by growth in Koser's citrate (Koser, 1924) modified by the addition of $1.5 \%$ (w/v) Ionagar (Difco Labs., Detroit, Michigan) and inoculation by the replica plate technique. Reaction in Simmons's citrate (Simmons, 1926) was determined on agar slopes.

Oxidation of calcium lactate through acetate to carbonate and the utilization of $0.3 \%$ sodium malonate, $0 \cdot I \%$ sodium acetate, $0.1 \%$ sodium formate as carbon source and $0.1 \% \mathrm{NH}_{4} \mathrm{H}_{2} \mathrm{PO}_{4}$ as nitrogen source were tested (160-164). For the nutritional 
tests, a basal salts agar containing $0.00025 \%$ yeast extract and $0.1 \%$ peptone for strains other than the Agrobacterium and Rhizobium species was used. Details of these procedures were as cited by Colwell (1964). Tests for utilization of the carbon or nitrogen source were always done by comparison with a control plate containing only the basal salts medium or basal salts medium containing $.00025 \%$ yeast extract and $+0.1 \%$ peptone where incorporated into the test medium.

The utilization of amino acids as carbon and nitrogen source (165-176) was determined from basal salts agar with $0.00025 \%$ yeast extract and $0.1 \%$ of the test amino acid added. The amino acids were filter-sterilized, except for tyrosine and cystine which were steamed for $\mathrm{I} \mathrm{hr}$ on three successive days and used at a final concentration of $0.05 \%$. Ionagar (Difco Labs., Detroit, Michigan) was used in the nutritional studies and inoculations were by the replica plating technique. Amino acids tested included: L-ornithine monochloride; L-arginine hydrochloride; L-lysine; L-alanine; L-histidine; L-serine; L-phenylalanine; L-proline; L-leucine; L-glutamic acid; L-cystine; L-tyrosine.

Growth, fluorescence, and production of 2-ketogluconate from potassium gluconate in Paton medium (Paton, 1959) were scored (I77-1 79). Growth in Haynes medium and production of 2-ketogluconate from gluconate (Haynes, 195I) was also recorded (I80-I8I).

Arginine dihydrolase and the arginine, ornithine and lysine decarboxylases (182-185) were tested following the methods of Thornley (1960) and Moeller (I955).

Methylene blue reduction (I86) was determined by adding I \% aqueous methylene blue to a 48-hr (fast-growing organisms) or 4-day (slow-growers) YM and YMP broth culture and incubating for $\mathrm{I} h \mathrm{hr}$.

Pectate hydrolysis (187) was detected by the method of Starr (1947).

Ability to produce penicillinase (I88) was determined by the technique described by Foley \& Perret (1962).

The methods for production of phenylpyruvic acid and/or melanin from phenylalanine and production of melanin from tyrosine (189-191) were as cited by Colwell (1964).

The results were scored for computation by recording positive reaction, i.e. growth present or positive test result, as unit features ' $I$ ', and negative reaction, i.e. no growth or negative test result as ' 0 '. In this study all organisms were tested for all features; however, the programs for analyisng the data were written so that tests not done or not applicable might be scored ' 3 '. The computer then did not include these entries in similarity comparisons.

An IBM I620 computer, Model II, with I3I I Disk Pack System, was used in the numerical analyses of the data. The programs where the $S$ value was calculated, comparing positive matches, and the $M$ value, comparing positive and negative matches, have been documented for the IBM 1620 Computer User's Library (GTP-2 and GTP-5). The frequency of feature occurrence within the major clusters (IBM Program GTP-3) followed the method of Colwell (1964).

The median organism was obtained by computer by using the program GTP-4 based on the method described by Liston, Wiebe \& Colwell (1963). 
M. L. MOFFETT AND R. R. COLWELL

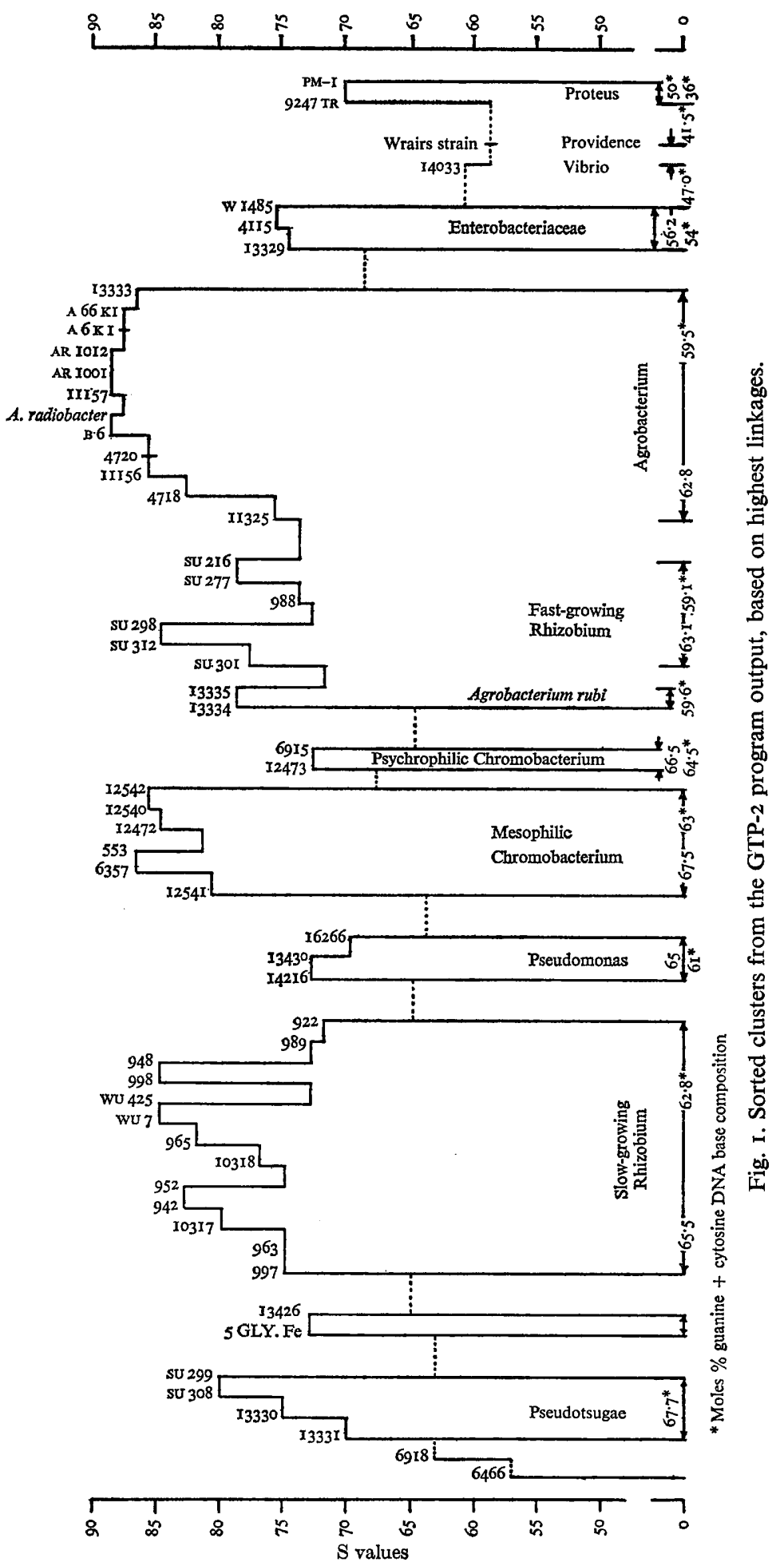




\section{RESULTS}

The groupings obtained by using $\mathrm{S}$ values from the computer analysis of the taxonomic data for the 59 strains included in the study are presented in Fig. I. As seen from Fig. I, at $S \geqslant 70$, eight clusters were formed. The three major clusters of related strains consisted of: slow-growing Rhizobium strains $S \geqslant 72$; Agrobacterium species and the fast-growing Rhizobium strains at $S \geqslant 72$; and the mesophilic Chromobacterium strains $\mathrm{S} \geqslant 8 \mathrm{r}$. The minor clusters were: Agrobacterium pseudotsugae and two fast-growing Rhizobium strains at $S \geqslant 70$; strain 5 GLY.FE with Chromobacterium violaceum strain 13426 at $S=73$; the Pseudomonas species which grouped at $S \geqslant 70$; psychrophilic Chromobacterium strains grouping at $S \geqslant 73$; and Proteus species, $\mathrm{S} \geqslant 70$.

The M-value calculation (Silvestri, Turri, Hill \& Gilardi, I962), in which shared negative features are taken into account in computing strain similarities, was also applied to the taxonomic data for the 59 strains. The clusters which formed were found to be essentially the same as those grouped by means of S-value relationships. The main difference, however, was that from $\mathbf{M}$-value computations, strains clustered at what could be interpreted as a much higher degree of similarity, namely the slowgrowing Rhizobium strains clustering at $M \geqslant 85$. Genus or species inter- and intrarelationships were difficult to interpret from inspection of the M-value output. In fact, the strains studied were merged into two major groups at $M \geqslant 80$. In Fig. 2 the groups sorted by shared $\mathrm{M}$-values of $80 \%$ or greater are presented.

Fig. 2. Cluster output from GTP-2 showing groups forming at $\mathrm{M}=80 \%(\mathrm{M}=$ 'Matching coefficient' of Silvestri et al. 1962).

Group I: (16266) P. fluorescens var. antirrhinastri+(13430) P. fluorescens+(14216) $P$. aeruginosa $+(922)$ Rhizobium sp. + (988) Rhizobium sp. + (948) Rhizobium sp. + (998) Rhizobium sp. $+($ WU 425) Rhizobium sp. $+($ wU 7) R. lupini + (965) Rhizobium sp. +(I0318) R. lupini + (952) R. japonicum + (942) Rhizobium sp.+(10317) Rhizobium sp.+ (963) Rhizobium sp. + (997) Rhizobium sp. +(13426) C. violaceum + (5 Gly. Fe) A. tumefaciens + su 299 R. leguminosarum $+($ (sU 308) R. trifolii $+(13330)$ A. pseudotsugae $+($ (1333I) A. pseudotsugae + (6466) $A$. radiobacter.

Group 2: (W I485) E. coli+(4II5) E. aerogenes + (13329) A. gypsophilae+(4718) A. tumefaciens + (I I I56) A. tumefaciens + (AR IOI2) A. radiobacter +A. radiobacter+ (I I I57) A. tumefaciens + (AR IOOI) A. radiobacter + (B 6) A. tumefaciens + (A $6 \mathrm{KI})$ A. tumefaciens + (A $66 \mathrm{KI}$ ) A. tumefaciens $+(4720) A$. tumefaciens + (13333) $A$. rhizogenes $+(11325)$ A. rhizogenes + (sU 277) $R$. meliloti +(su 216) $R$. meliloti $+(988)$ Rhizobium sp. +(su 301 ) $R$. leguminosarum + (su 312) $R$. phaseolit(su 298) R. trifolii+(I3335) A. rubi+(I3334) A. rubi.

Group 3: (6915) C. amethystinum $+(12473) C$. lividum $+(\mathbf{P} 66) X$. phaseoli $+(12542) C$. violaceum $+(\mathrm{I} 2540)$ C. violaceum $+(\mathrm{I} 2472)$ C. violaceum $+(533)$ C. violaceum $+(6375) C$. violaceum $+(12541)$ C. violaceum.

Group 4: (PM-I) $P$. mirabilis + (9247 TR) $P$. morgani.

Group 5: (I7) Pseudomonas + P. viscosa + (P 5I) P. atrofaciens + (P 8) P. atrofaciens + (P 9) P. coronafaciens + (P 28) P. lachrymans + (P 26) P. pisi + (P I I) P. pisi + (P 33) P. phaseolicola + (P 3) P. phaseolicola + (P 10) P. glycinea.

Group 6: (4358) $F$. arborescens $+(8315) F$. flavescens $+(958) F$. suaveolens $+(338) P$. maltophila + (I6) A. radiobacter.

Group 7: (BS) Alc. faecalis + (I4 L) Pseudomonas + Achr. iophagus.

Group 8: (SM IO) S. marcescens+(SMI) S. marcescens+(SM 2I) S. marcescens.

The $\mathrm{S}$ value relationship $\left(\mathrm{S}=N S / N_{s}+N_{D}\right.$, where $N_{s}=$ number of similar matches and $N_{D}=$ number of dissimilar matches, i.e. features positive for one strain but not the other and vice versa) were used for subsequent analyses of the taxonomic data. In Fig. 3 the formation of the groups can be followed. Eleven groups formed at 
Fig. 3. Cluster output from GTP-2 showing groups formed at selected levels of similarity based on S-value calculations (Sokal \& Sneath, 1963).

Clustering at $\mathbf{S}=80$.

Group I: (948) Rhizobium sp.+(998) Rhizobium sp.

Group 2: (WU 425) Rhizobium sp.+ (wU 7) R. lupini.

Group 3: (952) R. japonicum + (942) Rhizobium sp.+ (10317) Rhizobium sp.

Group 4: (sU 308) $R$. trifolii + (sU 299) R. leguminosarum.

Group 5: (sU 312) $R$. phaseolit((su 298) R. trifolii.

Group 6: (4718) A. radiobacter+(II156) A. tumefaciens+(4720) A. tumefaciens+(B 6)

A. tumefaciens $+A$. radiobacter + (I1157) A. tumefaciens + (AR 1001) A. radiobacter + (AR IOI 2)

A. radiobacter+( 6 RI) A. tumefaciens + (A $66 \mathrm{RI}) A$. tumefaciens +(13333) A. rhizogenes.

Group 7: (12542) C. violaceum $+(12540)$ C. violaceum $+(12472)$ C. violaceum $+(553) C$. violaceum $+(6357)$ C. violaceum $+(1254 \mathrm{r})$ C. violaceum.

Group 8: (P 5I) P. atrofaciens $+(\mathrm{P} 8) P$. atrofaciens $+(\mathrm{P} 9) P$. coronafaciens.

Group 9: (P II) $P$. pisi $+\left(\begin{array}{l}P \\ 26\end{array}\right) P$. pisi $+\left(\begin{array}{l}P \\ 28\end{array}\right)$. lachrymans.

Group I0: (609) Alc. faecalis + (14 L) Pseudomonas.

Group II: (SM IO) S. marcescens+(SMI) S. marcescens+(SM 21) S. marcescens.

Clustering at $S=75$.

Group I: (948) Rhizobium sp.+(998) Rhizobium sp.

Group 2: (wU 425) Rhizobium sp.+ (wU 7) R. lupini + (965) Rhizobium sp. + (10317) Rhizobium sp.+(10318) R. lupini + (952) R. japonicum $+(942)$ Rhizobium sp.+(963) Rhizobium sp. + (997) Rhizobium sp.

Group 3: (sU 216) R. meliloti $+($ (sU 277) R. meliloti.

Group 4: (sU 30I) R. leguminosarum+(sU 3I2) R. phaseoli+(sU 298) R. trifolii.

Group 5: (13330) A. pseudotsugae+(su 308) R. trifolii +(su 299) R. leguminosarum.

Group 6: (II 325) A. rhizogenes + (4718) A. radiobacter+(II I56) A. tumefaciens + (4720)

A. tumefaciens + (B 6) $A$. tumefaciens $+A$. radiobacter + (III57) A. tumefaciens + (AR IOOI)

A. radiobacter+(AR IOI2) A. radiobacter+(A $6 \mathrm{RI}) A$. tumefaciens+(A $66 \mathrm{RI}) A$. tumefaciens $+(13333)$ A. rhizogenes.

Group 7: (13334) A. rubi+(13335) A. rubi.

Group 8: (12542) C. violaceum $+(12540)$ C. violaceum $+(12472)$ C. violaceum $+(553)$

C. violaceum $+(6357)$ C. violaceum $+(12541)$ C. violaceum.

Group 9: (W I485) E. coli +(4II5) E. aerogenes +(13329) A. gypsophilae.

Group Io: (P 53) P. phaseolicola + (P ii) P. pisi+ (P 26) P. pisi +(P 28) P. lachrymans + (P 8)

$P$. atrofaciens $+(\mathrm{P} 9) P$. coronafaciens + (P 3) $P$. phaseolicola.

Group I I: (609) Alc. faecalis + (14 L) Pseudomonas.

Group 12: P. viscosa +(17) Pseudomonas.

Group I3: (SM IO) S. marcescens+(SMI) S. marcescens+(SM 2I) S. marcescens.

Clustering at $S=70$.

Group 1: (922) Rhizobium sp.+ (989) Rhizobium sp + (948) Rhizobium sp.+(998) Rhizobium sp. + (wU 425) Rhizobium sp. + (wU 7) R. lupini $+(965)$ Rhizobium sp. + (10318) R. lupini +(952) R. japonicum + (942) Rhizobium sp. +(10317) Rhizobium sp. $+(963)$ Rhizobium sp.+ (997) Rhizobium sp.

Group 2: (13334) $A . r u b i+(13335) A . r u b i+(\mathrm{su} 301) R$. leguminosarum+(su 312) $R$. phaseoli + (sU 298) R. trifolii +(998) Rhizobium sp. + (su 277) R. meliloti +(sJ 216) R. meliloti + (I I325) A. rhizogenes $+(47 \mathrm{I} 8) A$. radiobacter+(III56) $A$. tumefaciens $+(4720) A$. tumefaciens + (B 6) A. tumefaciens $+A$. radiobacter+(III57) A. tumefaciens + (AR IOOI) A. radiobacter+(AR I012) A. radiobacter+(A 6 RI) A.tumefaciens +(A 6 RI) A. tumefaciens +(13333) A. rhizogenes.

Group 3: (1333I) A. pseudotsugae + (13330) A. pseudotsugae +(su 308) R. trifolii +(su 299)

R. leguminosarum.

Group 4 : (12473) C. lividum $+(6915)$ C. amethystinum.

Group 5: ( 1 60) X. phaseoli $+(12542) C$. violaceum $+(12540) C$. violaceum $+(12472) C$. violaceum $+(6357)$ C. violaceum $+(553)$ C. violaceum + (1254I) C. violaceum.

Group 6: (I6266) P. fluorescens var. antirrhinastrit (13430) P. fluorescens $+(14216) P$. aeruginosa.

Group 7: (SM 10) S. marcescens+(SMI) S. marcescens +(SM 2I) S. marcescens+(13329) A. gypsophilae +(4II5) E. aerogenes + (W 1485) E. coli.

Group 8: (PM-I) P. mirabilis $+(9247$ TR) P. morgani.

Group 9 (I3426) C. violaceum + (5 GLY. FE) A. tumefaciens.

Group 10: (P IO) P. glycinea+(P 33) P. phaseolicola +(P II) P. pisit ( (P 26) P. pisit (P 28) P. lachrymans +(P 8) P. atrofaciens + (P 5I) P. atrofaciens +(P 9) P. coronafaciens +

(P 3) P. phaseolicola.

Group I I : (609) Alc. faecalis + (14 L) Pseudomonas.

Group 12: P. viscosa+(17) Pseudomonas. 
$S \geqslant 80,13$ groups at $S \geqslant 75$, and $\mathbf{I} 2$ groups at $S \geqslant 70$. Figures 2 and 3 also include the data for other reference strains retrieved from the computer data library. As can be seen from Figs. I and 3, separation of the Rhizobia and Agrobacteria from Chromobacterium, Pseudomonas, Serratia, Enterobacter, Escherichia, and Proteus species was at S-value levels of $<70 \%$.

From examination of Fig. 3 certain results may be noted. The slow-growing Rhizobia and the fast-growing Rhizobia/Agrobacteria clusters are distinct, forming from pairs at $\mathrm{S} \geqslant 80$ into the two clusters at $\mathrm{S} \geqslant 70$. The strains Agrobacterium pseudotsugae I3330 and 1333I, Rhizobium trifolii SU 308 and $R$. leguminosarum sU 299 formed a separate and distinct cluster, unrelated to the two major groups. DNA base-composition data available for these strains (see Fig. I) indicated a significantly different overall guanine + cytosine DNA base composition for these strains when compared with strains of the two major groups. Other DNA base composition data for these groups also correlated well with the sorting of the strains obtained from the computer analysis.

Agrobacterium gypsophilae 13329 shared high relationships with the strains of Escherichia coli, Enterobacter aerogenes and Serratia marcescens $(\mathrm{S}=70$, group '7; Fig. 3). An electrophoretic study of the isozymes and protein patterns of $A$. gypsophilae and other agrobacteria currently underway in our laboratories has provided confirmatory evidence for removing $A$. gypsophilae from the agrobacteria (P. K. Chen, personal communication).

Proteus strains $(S=70$, group 8$)$ did not cluster with other strains representing the Enterobacteriaceae ( $S=70$, group 7). Soil isolates labelled by other investigators as Pseudomonas species ( $\mathrm{S}=70$, group $\mathrm{I0}$ ) did not cluster with Pseudomonas fluorescens and $P$. aeruginosa $(\mathrm{S}=70$, group 6 ). These strains and the strains of groups II and $\mathrm{I} 2$ will be considered in a separate publication.

The Chromobacterium strains formed two major clusters corresponding to the mesophilic (C. violaceum) and psychrophilic (C. lividum) groups described by Sneath (I960). These two groups joined at $\mathrm{S}=68 \%$. The single strain of $C$. viscosum which was tested did not cluster with the Chromobacterium groups but rather joined at a low level $(\mathrm{S}=63 \%)$ to the Rhizobium and $A$. pseudotsugae strains. Also, as noted above, $C$. violaceum $\mathrm{I} 3426$ joined only with $A$. tumefaciens 5 GLY. FE and neither of these strains shared significantly high similarities with any of the other isolates tested.

Thus, intra-group relationships for the Rhizobiaceae, and inter-group relationships for the family with the Pseudomonadaceae and Enterobacteriaceae can be observed from Fig. I. Relationships with Serratia, Flavobacterium, Alcaligenes and Xanthomonas strains tested are given in Figs. 2 and 3.

The characters shared by all strains of the species and genera comprising the family Rhizobiaceae examined in the present study are listed in Tables 2 and 3. Thus, all the strains tested as Gram-negative rods, I-3 $\mu$ length $\times 0 \cdot 6-\mathrm{I} \cdot 0 \mu$ width, round-ended, motile, and occurring mainly as single or paired cells. Colonies on YM and YMP agar were I-2 mm diameter, convex, opaque, and entire. Growth within the temperature range $20-30^{\circ}, \mathrm{pH} 6-8$, and $\mathrm{NaCl}$ concentration of $0-0.5 \%$ was noted. All members of the Rhizobiaceae studied were catalase-positive. None of the strains produced a capsule detectible by the method employed. None grew in YM or YMP broth with $\mathrm{NaCl}$ added to final concentrations of $5 \%$ or greater. None produced gas from carbohydrates, acetic acid from ethanol, dihydroxyacetone from glycerol, or a urease detectible within $48 \mathrm{hr}$. The strains were all methyl-red negative and Voges-Proskauer 
negative. None of the strains demonstrated starch or pectate hydrolysis, agar digestion, or production of phenylpyruvic acid from phenylalanine. All strains were negative for hydrogen sulphide production in lead acetate agar but positive tests were recorded when other methods were employed for hydrogen sulphide production (see Table 4). The characters which were variable for the groups are listed in Table 4.

Table 2. Positive characters, i.e. feature frequency of $I \cdot 00$, for the major groups defined by the computer analysis: (I) slow-growing Rhizobium; (2) Agrobacterium/fast-growing Rhizobium; and (3) Chromobacterium.

\begin{tabular}{|c|c|c|c|}
\hline Character & & Character & \\
\hline no. & Character & no. & Character \\
\hline I & Straight rods & 19 & Gram-negative \\
\hline 6 & $\begin{array}{l}\text { Predóminant arrangement as single } \\
\text { cells }\end{array}$ & $24,26,28$ & $\begin{array}{l}\text { Convex, opaque colonies with } \\
\text { entire edge }\end{array}$ \\
\hline 9 & Round ends & 95,96 & $\begin{array}{l}\text { Growth within temperature } \\
\text { range } 20-30^{\circ}\end{array}$ \\
\hline 12 & I $-3 \mu$ length & 103, 104 & $\begin{array}{l}\text { Growth at } \mathrm{NaCl} \text { concentrations } \\
0-0.5 \%\end{array}$ \\
\hline I4 & $0 \cdot 6-\mathrm{I} \cdot 0 \mu$ width & I I $2-114$ & Growth within $\mathrm{pH}$ range $6.0-8.0$ \\
\hline 16 & Motile & II9 & Catalase-positive \\
\hline
\end{tabular}

Table 3. Negative characters, i.e. feature frequency of o, for the major groups defined by the computer analysis: (I) slow-growing Rhizobium; (2) Agrobacterium/fast-growing Rhizobium; and (3) Chromobacterium

\begin{tabular}{|c|c|c|c|}
\hline Character & & Character & \\
\hline no. & Character & no. & Character \\
\hline 2 & Curved rods & 88 & Agar digestion \\
\hline 3 & (Oval) spheres & 90 & Methyl-red reaction \\
\hline 4 & Filaments & 91 & Voges-Proskauer reaction \\
\hline 5 & Refractile cells & 108 & Growth in $10 \% \mathrm{NaCl}$ \\
\hline 10 & Tapered end & 147 & $\begin{array}{l}\mathrm{H}_{2} \mathrm{~S} \text { produced from peptone in } \\
\text { lead acetate agar }\end{array}$ \\
\hline I I & Spiral (rods) & 150 & Urease production $(48 \mathrm{hr})$ \\
\hline 35 & Capsule & $.15 \mathrm{I}$ & Indole production \\
\hline 41 & Pellicle formation in YM broth & 157 & 3-ketolactose production \\
\hline 50 & Glucose, gas production & I 84 & Ornithine decarboxylase \\
\hline 53 & $\begin{array}{l}\text { Acetic acid production from } \\
\text { ethanol }\end{array}$ & 185 & Lysine decarboxylase \\
\hline 86 & Starch hydrolysis & I 87 & Pectate hydrolysis \\
\hline 87 & $\begin{array}{l}\text { Dihydroxyacetone production } \\
\text { from glycerol }\end{array}$ & 189 & $\begin{array}{l}\text { Phenylpyruvic acid production } \\
\text { from phenylalanine }\end{array}$ \\
\hline
\end{tabular}

The slow-growing Rhizobium species cluster demonstrated, in addition to the characters listed in Tables 2 and 3 , the following features: polar flagella; mucilaginous colonies; metachromatic granules; a slight turbidity in YM broth; little or no detectible utilization of carbohydrates; production of levan; growth in the temperature range $15-37^{\circ}$; tolerance of $\mathrm{NaCl}$ in concentrations up to $3.0 \%$; growth in the $\mathrm{pH}$ range 4-8; oxidase positive; no sensitivity to the $0 / 129$ pteridine compound or to polymyxin $\mathrm{B}$ and marked sensitivity to $\mathrm{HgCl}_{2}$ at $\mathrm{Io} \mu \mathrm{g}$. concentration; production of an alkaline reaction in litmus milk and a detectible penicillinase. Of the characters for which the strains tested uniformly negative, the following may be noted: phosphatase; nitrite reduction; gelatin liquefaction; litmus milk peptonization; casein hydrolysis; 
Table 4. Characters with the variable frequency of occurrence amongst the major groups and subgroups defined by the computer analysis

Characters with frequency of occurrence $0-0.25$, scored $(-)$, or $0.75^{-1}$, scored $(+)$, were selected and tabulated. The sequence of characters as listed is as coded for the computer. For details of methods for performing tests, scoring, etc., see Methods. $\pm=$ Variable occurrence within the set of strains tested. Actual frequency of occurrence is given in parentheses.

Cha-

rac-

ter

no.

17

18

22

34

36

45

46

$4^{8}$

49

Agrobacterium/fast-growing Rhisobium

A. radio-
bacter

Slowgrowing Character Rhizobium

\section{Chromobacterium}

C. violaceum

$-1$

Morphological and cultural:

Polar flagella

Peritrichous flagella

Colony size $\mathrm{I}-2 \mathrm{~mm}$

+
+

dia.

Mucilaginous colonies $+(0.92)$

Metachromatic granules

Slight turbidity in

YM broth

Moderate turbidity in

YM broth

Carbohydrates:

Glucose (Hugh \&

Leifson, 1953) oxida-

tive, Acid

Glucose (Hugh \&

Leifson, 1953) fermen-

tative, Acid

Glucose+iodoacetate growth

Glucose + iodoacetate, acid

Maltose, acid

Lactose, acid

Sucrose, acid

Galactose, acid

Mannitol, acid

Terminal pH in glu-

cose fermentation

pH 6.5-7.0

pH 5.0-6.0

Adonitol, acid

Arabinose, acid

Cellobiose, acid

Dextrin, acid

Dulcitol, acid

Fructose, acid

Glycerol, acid

Inositol, acid

Inulin, acid

Mannose, acid

Melibiose, acid

Melezitose, acid

Raffinose, acid

Rhamnose, acid

Salicin, acid

C. livi-
dum*

tume-

faciens

rhizogenes

$$
\begin{aligned}
& + \\
& + \\
& +
\end{aligned}
$$$$
\begin{array}{lll}
+ & + & - \\
+ & + & +
\end{array}
$$$$
+\quad+(0.75)
$$

R. meli-

R. legumi-
nosarum $\begin{array}{cc}\text { Roti } & \text { trifolii } \\ \text { loti }^{*} & \text { phaseoli }\end{array}$

A. rubi* 
Table 4. (Continued)

Cha-

rac-

ter

no.

$8 \mathrm{I}$

82

83

84

85

89

93

94

97

98

IOI

105

106

109

IIO

I 6

I 17

120

I 2 I
Agrobacterium/fast-growing Rhizobium

A. radio-

bacter

tume-

Slow-

Chromobacterium

faciens

growing

C. vio-

C. livi-

dum* rhizogenes

R. meli-

R. legumi-

Character

Sorbitol, acid

Trehalose, acid

Xylose, acid

$5 \%$ Ethanol, acid

Aesculin hydrolyzed

Levan produced

Physiological:

Growth at $5^{\circ}$

Growth at $15^{\circ}$

Growth at $35^{\circ}$

Growth at $37^{\circ}$

Growth at $42^{\circ}$

Growth in $3.0 \% \mathrm{NaCl}$

Growth in $5.0 \% \mathrm{NaCl}$

Growth at $\mathrm{pH} 4 \cdot 0$

Growth at $\mathrm{pH} 4 \cdot 5$

Growth at $\mathrm{pH}$ 10.0

(Kovacs) oxidase

Phosphatase

Antibacterials:

Sensitivity to o/129

pteridine compound

Sensitive to:

Penicillin, Io units $\quad-(0.15)$

Dihydrostreptomycin, $\pm(0.6 \mathrm{I})$

Io $\mu \mathrm{g}$.

Chloromycetin, $30 \mu \mathrm{g} . \quad-(0.23)$

laceum

$+\quad+(0.75)$

$\begin{array}{ccc}- & -(0.17) & + \\ - & +(0.83) & - \\ \pm(0.38) & - & \pm(0.50)\end{array}$

$-(0.08)$

$-(0 \cdot 17)$

$(0.75)$
+

$+(0.92)$

$\pm(0 \cdot 6 \mathrm{I})$

$-(0 \cdot 17)$

-
+
$\pm(0 \cdot 50)$

$\pm(0 \cdot 33)$

$+$

$+(\overline{0} \cdot 77)$

+
$+(0 \cdot 85)$

-
+
+
+

$\pm(0 \cdot 30)$

$+$

$$
\begin{aligned}
& - \\
& + \\
& +
\end{aligned}
$$

+
+
+

$\pm(0.66)$

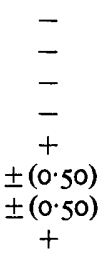

$+$

$+(0 \cdot 92)$

$-(0.08)$

$+$

$\pm(0.67)$

$\pm(0 \cdot 58)$

$+$

$\pm(0 \cdot 83)$

$\pm(0 \cdot 50)$

+
+
+
-
$\pm(0.50)$
+

trifolii

phaseoli

A. rubi*

$+$

$\pm(0.50)$

$+$

$\pm(0 \cdot 50)$

$+$

Erythromycin, I5 $\mu \mathrm{g}$.

Kanamycin, $30 \mu \mathrm{g}$.

Aureomycin, $30 \mu \mathrm{g}$.

Novobiocin, $30 \mu \mathrm{g}$

$$
-(0.23)
$$

$\pm(0 \cdot 69)$

$+(0 \cdot 77)$

$\pm(0 \cdot 69)$

Polymyxin B, 300 units

Terramycin, $30 \mu \mathrm{g}$

Tetracycline, $30 \mu \mathrm{g}$.

$-$

$\pm(0 \cdot 46)$

$+(0 \cdot 85)$

$+(0.92)$

$\mathrm{HgCl}_{2}$, $10 \mu \mathrm{g}$.

Biochemical tests

Nitrate reduced to

$+$

$+(0.85)$

nitrite

Nitrite reduced

Gelatin liquefied

Litmus milk,

peptonized

Litmus milk, alkaline

Casein hydrolysed

Ammonia produced in

peptone water

Hydrogen sulphide $\quad \pm(0 \cdot 46)$

$+(\overline{0} \cdot 83)$

$\pm(0 \cdot 50)$

$-(0.17)$

$\pm(0 \cdot 50)$

$\pm(0 \cdot 66)$

$\pm(0 \cdot 50)$

-
+
+
+
$\pm(0 \cdot 50)$

$+$

$\pm(0.50)$

$+$

$+$

-
+
$\pm(0.33)$
-
-
+
-
$\pm(0.33)$
+
-
$\pm(0.66)$

$+$

$+$

$+$

$+$

$+$

$+$

+
+
+

$+$

$\pm(0.50)$

$\pm(0 \cdot 50)$

$+(0.83)$

$+\quad+(0.92)$

$$
\pm(0.33)
$$

$+$

+
$+(0.83)$

$+++(0.83)$

$+$

$+$

$+$

$\pm(0.50)$

$+$

$+$

$-(0.08)$

$+$

$\frac{t}{+}$

$+$

$+$$$
+
$$

$+$

$\pm(0.66)$

$\pm(0.66)$

$+$

$+$

$+$

$+$

- $\pm(0.50)$

$\begin{array}{ccc} \pm(0.50) & \pm(0.50) & \pm(0.58) \\ + & \pm(0.50) & -\end{array}$

$-\quad+$

$+$

$+$

$-\quad+\quad+(0.92)$

$+$

$\pm(0.42)$

+
$\frac{-}{ \pm(0.50)}$

$+$

$+$

$\pm(0.66)$

Hydrogen sulphide $\quad \pm(0.69)$ cystine produced from cysteine 
Table 4. (Continued)

\begin{tabular}{|c|c|c|c|c|c|c|c|c|}
\hline \multirow{3}{*}{$\begin{array}{l}\text { Cha- } \\
\text { rac- } \\
\text { ter } \\
\text { no. }\end{array}$} & \multirow[b]{3}{*}{ Character } & \multirow{3}{*}{$\begin{array}{c}\text { Slow- } \\
\text { growing } \\
\text { Rhizobium }\end{array}$} & \multirow{2}{*}{\multicolumn{2}{|c|}{ Chromobacterium }} & \\
\hline & & & & & \multirow{2}{*}{$\begin{array}{l}\text { A. radio- } \\
\text { bacter } \\
\text { tume- } \\
\text { faciens } \\
\text { rhizogenes }\end{array}$} & \multirow[b]{2}{*}{$\underset{\text { loti }^{*}}{R . \text { meli- }}$} & \multirow{2}{*}{$\begin{array}{l}\text { R. legumi- } \\
\text { nosarum } \\
\text { trifolii } \\
\text { phaseoli }\end{array}$} & \multirow[b]{2}{*}{ A. rubi* } \\
\hline & & & $\begin{array}{l}\text { C. vio- } \\
\text { laceum }\end{array}$ & $\begin{array}{l}\text { C. livi- } \\
\text { dum }^{*}\end{array}$ & & & & \\
\hline 150 & Urease (I week) & $\pm(0.69)$ & $\pm(0.50)$ & $\pm(0.50)$ & + & + & + & + \\
\hline 152 & Lecithinase & - & + & $\pm(0.50)$ & - & - & - & - \\
\hline 153 & Lipase (Tweens 20, 40) & $+(0.85)$ & + & + & - & - & - & + \\
\hline 154 & Lipase (Tween 60) & $+(0.85)$ & + & $\pm(0 \cdot 50)$ & - & - & - & - \\
\hline 155 & Lipase (Tween 80) & - & + & $\pm(0 \cdot 50)$ & - & - & - & - \\
\hline 158 & $\begin{array}{l}\text { Growth in Koser's } \\
\text { citrate }\end{array}$ & $-(0.23)$ & + & + & $\pm(0 \cdot 66)$ & $\pm(0.50)$ & - & $\pm(0.50)$ \\
\hline 159 & Simmons citrate & - & $+(0.83)$ & $\pm(0.50)$ & - & - & - & - \\
\hline 160 & $\begin{array}{l}\text { Oxidation of calcium } \\
\text { lactate through acetate } \\
\text { to carbonate }\end{array}$ & - & + & + & + & + & $\pm(0 \cdot 66)$ & + \\
\hline & Nutrition: & & & & & & & \\
\hline $16 \mathrm{I}$ & $\begin{array}{l}\text { Utilization of } 0.3 \% \\
\text { sodium malonate as Cs }\end{array}$ & $\begin{array}{l}+(0 \cdot 77) \\
\text { source }\end{array}$ & - & + & $-(0.25)$ & + & $\pm(0.66)$ & + \\
\hline 162 & $\begin{array}{l}\text { Utilization of } 0.1 \% \\
\text { sodium acetate as C sol }\end{array}$ & urce $^{+}$ & - & $\pm(0.50)$ & + & + & + & + \\
\hline 163 & $\begin{array}{l}\text { Utilization of } 0 \cdot \mathrm{I} \% \\
\text { sodium formate as } \mathrm{C} \mathrm{sc}\end{array}$ & $\begin{array}{l}+(0.92) \\
\text { ource }\end{array}$ & $\pm(0.33)$ & $\pm(0.50)$ & + & + & $\pm(0 \cdot 66)$ & + \\
\hline 164 & $\begin{array}{l}\text { Utilization of } \\
\mathrm{NH}_{4} \mathrm{H}_{2} \mathrm{PO}_{4} \text { as N } \\
\text { source }\end{array}$ & - & $-(0.17)$ & + & $+(0.92)$ & + & $\pm(0.33)$ & $\pm(0.50)$ \\
\hline & Utilization as $\mathrm{C}$ and $\mathrm{N}$ so & urce: & & & & & & \\
\hline 165 & $\begin{array}{l}\text { Ornithine mono- } \\
\text { chloride }\end{array}$ & $\pm(0.69)$ & + & - & + & + & $\pm(0.66)$ & - \\
\hline I 66 & $\begin{array}{l}\text { Arginine hydro- } \\
\text { chloride }\end{array}$ & $\pm(0.31)$ & $\pm(0.67)$ & + & + & + & $\pm(0.66)$ & - \\
\hline I67 & L-lysine & $\pm(0.69)$ & + & + & $+(0.83)$ & + & - & - \\
\hline I 68 & L-alanine & $\pm(0.69)$ & + & + & + & + & + & - \\
\hline 169 & L-histidine & $-(0.23)$ & + & + & + & + & $\pm(0 \cdot 66)$ & + \\
\hline 170 & L-serine & $\pm(0.38)$ & $+(0 \cdot 83)$ & + & $+(0 \cdot 75)$ & + & $+(0.66)$ & - \\
\hline I7I & L-phenylalanine & $+(0.77)$ & + & - & $-(0.08)$ & + & $\pm(0.33)$ & - \\
\hline 172 & L-proline & $+(0.77)$ & $+(0.83)$ & + & + & + & $\pm(0.66)$ & - \\
\hline 173 & L-leucine & $\pm(0.69)$ & - & + & - & $\pm(0 \cdot 50)$ & - & - \\
\hline 174 & L-glutamic acid & $\pm(0.54)$ & + & $\pm(0.50)$ & $\pm(0 \cdot 42)$ & - & + & - \\
\hline I 75 & L-cystine & $\pm(0.54)$ & - & - & $-(0.08)$ & $\pm(0.50)$ & - & - \\
\hline 176 & L-tyrosine & $+(0.77)$ & + & + & $-(0.17)$ & $\pm(0.50)$ & + & - \\
\hline & Other: & & & & & & & \\
\hline 179 & $\begin{array}{l}\text { Production of 2-keto- } \\
\text { gluconate from } \\
\text { potassium gluconate }\end{array}$ & - & - & - & $-(0.08)$ & - & - & - \\
\hline 182 & Arginine dihydrolase & - & $\pm(0.33)$ & - & - & - & - & - \\
\hline I 83 & $\begin{array}{l}\text { Arginine } \\
\text { decarboxylase }\end{array}$ & - & + & - & $-(0.08)$ & - & - & - \\
\hline 186 & $\begin{array}{l}\text { Methylene-blue } \\
\text { reduction }\end{array}$ & - & $-(0 \cdot 17)$ & + & $+(0 \cdot 75)$ & - & - & - \\
\hline 188 & Penicillinase & + & $\pm(0 \cdot 33)$ & + & + & + & $\pm(0.66)$ & + \\
\hline 190 & $\begin{array}{l}\text { Melanin produced } \\
\text { from phenylalanine }\end{array}$ & - & $+(0 \cdot 83)$ & - & - & - & - & - \\
\hline $19 I^{\circ}$ & $\begin{array}{l}\text { Melanin produced } \\
\text { from tyrosine }\end{array}$ & - & $\pm(0.50)$ & + & $+(0.83)$ & - & - & - \\
\hline
\end{tabular}

Agrobacterium/fast-growing Rhizobium 
lecithinase; utilization of $\mathrm{NH}_{4} \mathrm{H}_{2} \mathrm{PO}_{4}$ as nitrogen source; production of 2-ketogluconate from gluconate; arginine decarboxylase; and methylene-blue reduction.

The Chromobacterium strains formed two clusters corresponding to the mesophilic (C. violaceum) and psychrophilic (C. lividum) strains described by Sneath (I960). These two groups joined at $\mathrm{S}=68 \%$. There were only a few characters in each group which varied from the descriptions provided by Sneath (1960). The data are presented in Table 4. The differences may be cited as follows. Mesophilic strain ATCC I254I produced acid from sorbitol. Chromobacterium strain no. I2540 did not produce acid from trehalose. Failure to produce acid from salicin, lactose and inulin, by the psychrophilic group agreed with Leifson's results (Sneath, 1960). However, the two strains in this group did not produce acid from mannitol. Growth was not detected in either

Table 5. $S$ value of Agrobacterium strains with the hypothetical median organism

\begin{tabular}{|c|c|c|c|}
\hline \multicolumn{2}{|r|}{ Strains } & $\mathbf{S}$ value & $\begin{array}{l}\text { No. of } \\
\text { tests* }\end{array}$ \\
\hline 11157 & A. tumefaciens & $94 \cdot 4$ & 107 \\
\hline A. RADIO & A. radiobacter & $92 \cdot 9$ & 112 \\
\hline AR IOOI & A. radiobacter & $92 \cdot 9$ & 112 \\
\hline в 6 & A. tumefaciens & $90 \cdot \mathrm{I}$ & I I I \\
\hline A 6 RI & A. tumefaciens & $87 \cdot 7$ & I I4 \\
\hline 4720 & A. tumefaciens & $87 \cdot 4$ & I 1 I \\
\hline A 66RI & A. tumefaciens & $86 \cdot 2$ & 116 \\
\hline AR 1012 & A. radiobacter & $85 \cdot 2$ & 115 \\
\hline 11156 & A. tumefaciens & $84 \cdot 2$ & 114 \\
\hline 4718 & A. radiobacter & 83.9 & 112 \\
\hline 13333 & A. rhizogenes & $82 \cdot 2$ & 118 \\
\hline 11325 & A. rhizogenes & $75 \cdot 4$ & I 18 \\
\hline
\end{tabular}

* Number of tests $\left(n_{s}+n_{d}\right)$ on which $\mathrm{S}$ value $\left(\mathrm{S}=n_{s} / n_{s}+n_{d}\right)$ is based. Total number of coded tests was 191 .

group with $3 \% \mathrm{NaCl}$ but all strains grew in the range $\mathrm{pH} 4.5-10 \cdot 0$ except strain no. 6915 which did not grow at $\mathrm{pH}$ 10.0. Pigment description was excluded from the tables because although all strains characteristically produced a dark blue nondiffusible pigment, this character was not stable, as non-pigmented or palely pigmented colonies frequently were present on agar plate streaking of a pure culture. De Ley (1964) made similar observations concerning the pigmentation of Chromobacterium.

Neither Chromobacterium cluster produced acid from adonitol, dulcitol, melibiose, melezitose or raffinose. Both groups possessed lipase (Tween 20, 40) and were sensitive to $\mathrm{HgCl}_{2}$, Io $\mu \mathrm{g}$. The two groups differed in several respects. The mesophiles were fermentative in glucose metabolism, were not sensitive to dihydrostreptomycin $10 \mu \mathrm{g}$., peptonized milk, hydrolysed casein, did not grow in a minimal medium with malonate or acetate as carbon source, and tested positive for arginine decarboxylase. The mesophiles utilized ornithine and phenylalanine as a nitrogen and carbon source while the psychrophiles utilized leucine. These features may be worth further analysis to determine their usefulness in diagnostic applications, since they represent metabolic functions most probably governed by gene complexes, and would therefore, as a combination, or plexus of features, provide a determinative key.

The Agrobacterium/fast-growing Rhizobium cluster, although divisible into four subgroups consisting of $A$. radiobacter $+A$. tumefaciens $+A$. rhizogenes, $R$. meliloti, 
R. leguminosarum $+R$. trifolii $+R$.'phaseoli, and $A$. rubi (Fig. I), have many features in common. Several differ from those scored for the slow-growing Rhizobium and the Chromobacterium clusters. In contrast to the slow growers, the Agrobacterium/fastgrowing Rhizobium cluster was peritrichously flagellated, slightly fermentative in glucose medium (decrease in $\mathrm{Ph}$ in fermentation tube) and produced acid in a number of the carbohydrates tested. The strains also were sensitive to Polymyxin B and lipase negative. These and other characters useful in distinguishing the subgroups of this cluster are listed in Table 4 .

Table 6. S value of slow-growing Rhizobium strains with the hypothetical median organism

\begin{tabular}{|c|c|c|c|}
\hline & Strain & $S$ value & $\begin{array}{l}\text { No. of } \\
\text { tests* }\end{array}$ \\
\hline 965 & Rhizobium sp. & $84 \cdot 2$ & 76 \\
\hline 998 & Rhizobium sp. & $82 \cdot 3$ & 79 \\
\hline 952 & $R$. japonicum & $82 \cdot 3$ & 79 \\
\hline 10318 & R. lupini & $8 \pi \cdot 8$ & 77 \\
\hline 942 & Rhizobium sp. & 80.5 & 82 \\
\hline 997 & Rhizobium sp. & $80 \cdot 5$ & 82 \\
\hline WU 7 & R. lupini & $79 \cdot 7$ & 74 \\
\hline 948 & Rhizobium sp. & $78 \cdot 3$ & 83 \\
\hline 10317 & Rhizobium sp. & $77 \cdot 8$ & 81 \\
\hline WU 425 & Rhizobium sp. & $75 \cdot 6$ & 78 \\
\hline 963 & Rhizobium sp. & $73 \cdot 2$ & 82 \\
\hline 989 & Rhizobium sp. & $73 \cdot 2$ & 82 \\
\hline & Rhizobium sp. & & 80 \\
\hline
\end{tabular}

* Number of tests $\left(n_{s}+n_{d}\right)$ on which the $\mathrm{S}$ value $\left(\mathrm{S}=n_{s} / n_{s}+n_{d}\right)$ is based. Total number of coded tests was 19I.

Table 7. $S$ value of Chromobacterium violaceum strains with the hypothetical median organism

$\begin{array}{llcc} & \text { Strain } & \text { S value } & \begin{array}{c}\text { No. of } \\ \text { tests* }\end{array} \\ 553 & \text { C. } \text { violaceum } & 90 \cdot 0 & 100 \\ 12472 & \text { C. violaceum } & 88 \cdot 3 & 103 \\ 12542 & \text { C. violaceum } & 87.6 & 105 \\ 1254 \mathrm{I} & \text { C. violaceum } & 86 \cdot 8 & 106 \\ 6357 & \text { C. } \text { violaceum } & 85 \cdot 6 & 104 \\ \mathrm{I} 2540 & \text { C. } \text { violaceum } & 82 \cdot 2 & 107 \\ 13426 & \text { C. violaceum } & 55 \cdot 9 & 118\end{array}$

* Number of tests $\left(n_{s}+n_{d}\right)$ on which the $\mathrm{S}$ value, $\mathrm{S}=n_{s}\left(n_{s}+n_{d}\right)$, is based. Total number of tests employed was I9I.

Hypothetical median organisms (Liston et al. 1963) were calculated for the Agrobacterium, slow-growing Rhizobium, and Chromobacterium violaceum groups. A measure of homogeneity of the clusters can be obtained from the tabulation of strain S-values of a cluster with the hypothetical median organism for that cluster. The Agrobacterium strains each share S-values $>75 \%$ with the hypothetical median organism (Table 5). Thus a suitable representative or neotype strain for this group, for example, would be $A$. tumefaciens III57 ( $\mathrm{S}=94 \%$ ).

Tables 6 and 7 contain S-value calculations of each strain with the respective hypothetical median strains for the other two groups which were analysed. Chromobacterium 
violaceum 13426, not a member of the $C$. violaceum cluster from the initial data results (Fig. I), yielded a very low S-value $(\mathrm{S}=56 \%)$ with the hypothetical median organism for the major $C$. violaceum cluster, reaffirming its lack of membership in the group.

Fig. 4. Inter-S-values computed from the hypothetical median organisms for the Agrobacterium, Chromobacterium violaceum, slow-growing Rhizobium and the $A$. pseudotsugae clusters.

\section{Slow-growing Rhizobium Agrobacterium A. pseudotsugae Chromobacterium violaceum}

\begin{tabular}{lrrrr} 
& \multicolumn{1}{c}{1} & 2 & 3 & 4 \\
\cline { 2 - 5 } 1 & 100 &. &. &. \\
2 & 45 & 100 &. &. \\
3 & 51 & 60 & 100 &. \\
4 & 46 & 48 & 53 & 100
\end{tabular}

Fig. 5. Inter-S-values for the median organisms of the Rhizobiaceae clusters and for other representative strains included in the study.

\begin{tabular}{|c|c|c|c|c|c|c|c|c|c|c|}
\hline 100 & & & & & & & & & & \\
\hline $4^{8}$ & 100 & & & & & & & & & \\
\hline 45 & 54 & 100 & & & & & & & & \\
\hline 43 & 53 & 46 & 100 & & & & & & & \\
\hline 51 & $5 I$ & 49 & 55 & 100 & & & & & & \\
\hline 46 & 58 & 55 & 52 & 70 & 100 & & & & & \\
\hline 42 & 54 & 53 & 57 & 73 & 68 & 100 & & & & \\
\hline $4^{2}$ & 46 & 57 & 52 & 49 & 52 & 55 & 100 & & & \\
\hline 35 & $5 \mathrm{I}$ & 62 & 52 & 53 & 62 & 64 & 76 & 100 & & \\
\hline 41 & 46 & 50 & 54 & 45 & 49 & $5 I$ & 53 & 57 & 100 & \\
\hline 42 & 45 & 50 & 53 & 46 & 49 & 49 & 55 & 52 & 70 & I0O \\
\hline $\mathscr{2}$ & $\begin{array}{l}\infty \\
\text { ర } \\
\text { p }\end{array}$ & 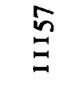 & $\tilde{n}$ & ঙ্ল্ড & $\begin{array}{l}\text { ర్ర } \\
\text { ర్ల }\end{array}$ & 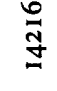 & \begin{tabular}{l} 
n \\
\multirow{y}{*}{} \\
3
\end{tabular} & $\Xi$ & $\sum_{i}^{J}$ & 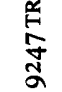 \\
\hline
\end{tabular}

By using the computed hypothetical median organisms for the four groups Agrobacterium, Chromobacterium (mesophilic), slow-growing Rhizobium and A. pseudotsugae, an S-value table of inter-group relationships was obtained (see Fig. 4). The Agrobacterium and the A.pseudotsugae groups shared S-value relationship of $60 \%$ but the other values for the groups were much lower. An ordering of the groups on the basis of hypothetical median organism similarities would thus be as given in Fig. 4 .

An S-value table for actual median organisms (selected on the basis of highest computed relationship with the hypothetical median strain for the given group) was computed for II of the species from the analysis (Fig. 5). The intra-S-value for the three Pseudomonas strains was $c .70 \%$ and for Escherichia coli W 1485 and Enterobacter aerogenes, 4115, 76\%, S-value levels which, from earlier studies (Colwell \& Liston, I96I), would be considered at least a generic level of similarity. The two Proteus species, showed a similar S-value, 70\%. The order in which the strains are listed in Fig. 5 represents a final arrangement based on the computed similarities amongst the strains as given in the triangular matrix. 


\section{DISCUSSION}

The relation of the Rhizobia to other bacteria, the relationships amongst the crown gall organisms, the root nodule organisms, Agrobacterium radiobacter, and the hairyroot lesion organism ( $A$. rhizogenes), and the division of the root nodule bacteria into two broad groups were problems facing the early students of soil bacteriology and remain to the present as points of debate amongst the workers in the field. As early as 1903 the Rhizobia were divided into two groups on the basis of cultural characteristics, including carbohydrate reactions, gelatin reaction, etc. (Fred, Baldwin \& McCoy, 1932). Löhnis \& Hansen (I92I) established both the so-called fast-growing Rhizobium group, characterized as producing rapid profuse slimy growth, appreciable acid formation and a 'serum zone' in milk, and the slow-growing group which exhibited slower, less profuse growth and an alkaline reaction in carbohydrate media and no change in milk. As a result of the work of Fred et al. (I932), 6 species were established for the nodule bacteria and the species were placed into the new genus Rhizobium (Bergey's Manual, 1957).

Lange (196I) clearly demonstrated that the cross-inoculation group separations of the rhizobia for species designation was not, in practice, satisfactory. Distinctly different host groupings were apparent from the data collected during his study of nodule bacteria associated with the indigenous legumes of south-western Australia. As pointed out by Lange, the economic importance attached to agronomic legumes and the resulting disproportionate attention to these has resulted in a skew classification of the nodule bacteria.

Lange's suggestion that an Adansonian analysis of the root nodule bacteria should be done was taken up by Graham (1964). Graham's analysis of strains of the genera Rhizobium, Agrobacterium, Chromobacterium, Beijerinckia and Bacillus provided some valuable new data. From the results of his analysis, Graham concluded that Chromobacterium, Bacillus and Beijerinckia showed little affinity with the nodule bacteria studied. The results of the analysis reported in the present work provide strong support for the separation of Chromobacterium from the other genera of the Rhizobiaceae. In fact, there seems little reason to retain the family as presently composed. Of the several genera included in the present analysis, the highest relationship of the Chromobacterium violaceum was to Pseudomonas aeruginosa ( $57 \% \mathrm{~S}$; see Fig. 5). The root nodule bacteria might better be placed in the family Pseudomonadaceae, a conclusion also arrived at by De Ley et al. (1966b) from DNA homology studies. Furthermore, the $C$. violaceum and $C$. lividum inter-species relationships were so low as to suggest treatment of these clusters as different genera.

Graham also pointed out that the genus Rhizobium required major revision and suggested, from his results, that $R$. trifolii, $R$. leguminosarum and $R$. phaseoli be consolidated into a single species, that Agrobacterium and $A$. tumefaciens be included as $R$. radiobacter in the genus Rhizobium and that the genus Phytomyxa be applied to the strains of slow-growing root-nodule bacteria. We find all of these suggestions most useful after examination of the results of our analyses. From Fig. I it is obvious that the major separation of the Rhizobium species is into the slow growers and the fast growers as originally described by Löhnis \& Hansen (192I). Generic level of separation, at the least, is clearly indicated. Since Buchanan (I926) concluded that the two names, Phytomyxa and Rhizobium, were available for 
the bacteria of leguminous plants, it seems logical for historical reasons to retain the fast-growers within the genus Rhizobium and include the slow-growers in the new genus Phytomyxa. The intra-generic relationships of the fast-growers and the Agrobacterium strains are not as clear-cut as Graham (1964) would imply. It is clear, however, that the results reported here support the consolidation of the remaining Rhizobium into two or more species. Our analysis would support retention of $R$. meliloti (strains SU 277 and sU 216, Fig. I) and R. leguminosarum (SU 30I, SU 3I 2, SU 298, Fig. I). However, besides Rhizobium radiobacter, into which we would place $A$. tumefaciens, $A$. rhizogenes and $A$. radiobacter, we would also propose the retention of species Rhizobium rubi, into which strains presently designated $A$. rubi, 13334 and I3335, should be placed.

Agrobacterium gypsophilae strain I 3329 should not be included in the Rhizobiaceae; that is, the results of the computer study indicate that it may more logically be placed in the family Enterobacteriaceae (see Fig. I).

The Agrobacterium pseudotsugae strains included in the present study would be not considered members of the species $R$. radiobacter, as were the other Agrobacterium species. Agrobacterium pseudotsugae appears to warrant a separate generic designation. De Ley, Park, Tijtgat \& Van Ermengem, I966 b) also questioned the relationship of A. pseudotsugae to the other agrobacteria on the basis of DNA base composition.

Genera, other than those of the Rhizobiaceae, which were studied provide some interesting information. Members of the Enterobacteriaceae formed two clusters linked via the Vibrio cholerae type strain 14033 (Hugh, 1965) and the four isolates of Serratia marcescens, data for which were included in the computations as they were available from an earlier study (Colwell \& Mandel, 1965). The genus Vibrio might better be placed in the family Enterobacteriaceae. Strains of the genus Vibrio are being studied in our laboratory in order to resolve this point.

The clustering together of the two strains 5GLY. FE, a non-virulent Agrobacterium tumefaciens strain and $C$. violaceum $\mathrm{I} 3426$, and the rather nebulous position of $A$. radiobacter strain 6466 and Chromobacterium viscosum 6918, were not readily explicable. In the case of $A$. radiobacter 6466 and $A$. tumefaciens 5 GLY. FE, misidentification by the persons isolating these strains may be the explanation for the anomalous results. Sneath (1960) also concluded that $C$. viscosum does not rightly belong in the genus Chromobacterium. The following facts should be made clear. In our hands, C. violaceum 13426 did not produce pigment under any of the conditions tested and C. viscosum produced a purple water-soluble pigment. None of the other Chromobacterium strains tested in this analysis produced a water-soluble pigment, the pigment being in every case restricted to intracellular location.

From the data in Table 7 it appears that $C$. violaceum 12472 , the proposed neotype strain (Sneath, 1960) was a suitable choice ( $\mathrm{S}=88 \%$ with the hypothetical median organism of the mesophilic cluster of the genus Chromobacterium). Other neotype strains, as indicated from Tables 5 and 6, would be II 57 for Rhizobium radiobacter and 965 for Phytomyxa japonicum.

Family relationships, as determined from Figs. 4 and 5 would result in the elimination of only Phytomyxa (represented by Rhizobium 965) and Proteus, if an inter-S level of $50-60 \%$ were selected as the demarcation. The lack of over-all similarity of Proteus species one to the other, as well as of the genus to the rest of the genera of the Enterobacteriaceae, was noted by Krieg \& Lockhart (1966). Perhaps, more 
logically, it would be better simply to order the genera, as was done in Fig. I, according to inter-group S-values, since the over-all DNA base compositions correlated extremely well with the intra- and inter-group arrangements thus obtained.

The feature frequency of occurrence for Rhizobium radiobacter and $R$. meliloti, R. leguminosarum and $R$. rubi for Phytomyxa japonicum and for Chromobacterium violaceum and $C$. lividum (Table 4) permit establishment of characteristics useful in forming descriptions for each of these species, independent as in the case of the Rhizobium and Phytomyxa species, of plant inoculation studies. These characteristics thus provide reference markers, or base-points, for purposes of comparison with new data obtained in future or may be employed in a determinative key for identifying the species of the genera listed.

It is important to emphasize that bacterial taxonomy is in a dynamic situation, a fluid state with new information constantly becoming available. As more knowledge concerning the biochemical pathways and genetic control mechanisms operating in these organisms is accumulated, it is to be expected that the descriptions and limits of the taxa proposed here will be appropriately altered.

This study was aided by research grants (GB 3363 and GB 6096X) from the National Science Foundation. The work of one of us (M. L. Moffet) who held a Fellowship ( 1966-67) from the American Association of University Women was also supported by a grant. Use of the computer facilities of the Georgetown University Computation Center made possible the extensive programming and computations carried out under the present study.

\section{REFERENCES}

Baird-PARKer, A. C. (1963). A classification of Micrococci and Staphylococci based on physiological and biochemical tests. J. gen. Microbiol. 30, 409.

BeIJerINCK, M. W. (I888). Die Bacterien der Papilion Aceenknöllchen Bot. Ztg. 46, 726, 74I, 757, $781,797$.

Bergey's Manual of Determinative Bacteriology (1957). 7th edition, ed. by R S. Breed, E. G. D. Murray and N. R. Smith. Baltimore: Williams and Wilkins Co.

Bernaerts, M. J. \& De LeY, J. (1963). A biochemical test for crown gall bacteria. Nature, Lond. r97, 406.

Bradshaw, L. J. (1964). Laboratory Microbiology. Philadelphia and London: W. B. Saunders Co.

BuChanAN, R. E. (1926). What names should be used for the organisms producing nodules on the roots of leguminous plants? Proc. lowa. Acad. Sci. 33, 8I.

Christensen, W. B. (1946). Urea decomposition as a means of differentiating Proteus and paracolon cultures from each other and from Salmonella and Shigella. J. Bact. 52, 46I.

Colwell, R. R. (1964). A study of features used in the diagnosis of Pseudomonas aeruginosa. J. gen. Microbiol. 37, I8I.

Colwell, R. R. \& Liston, J. (196I). Taxonomic relationships among the pseudomonads. J. Bact. 82, I.

Colwell, R. R. \& MANDel, M. (1965). Adansonian analysis and deoxyribonucleic acid base composition of Serratia marcescens. J. Bact. 89, 454.

Colwell, R. R.\& Quading, C. (I962). Miniature tubes in diagnostic bacteriology. Can. J. Microbiol. 8, 813.

DE LEY, J. (1964). Effect of mutation on DNA-composition of some bacteria. Antonie van Leeuwenhoek, 30, 28I.

De LeY, J. \& RASSel, A. (1965). DNA composition, flagellation and taxonomy of the genus Rhizobium. J. gen. Microbiol. 4I, 85.

De Ley, J., BernaerTs, M., Rassel, A. \& Guilmot, J. (1966a). Approach to an improved taxonomy of the genus Agrobacterium. J. gen. Microbiol. 43, 7. 
De Ley, J., Park, I. W., Tijtgat, R. \& van Ermengem, J. (I966 b). DNA homology and taxonomy of Pseudomonas and Xanthomonas. J. gen. Microbiol. 42, 43.

Fred, E. B., Baldwin, I. L. \& MCCoy, E. (1932). Root Nodule Bacteria and leguminous plants. Univ. Wisc. Stud. Sci. no. 5.

Foley, J. M. \& Perret, C. J. (1962). Screening colonies for penicillinase production. Nature, Lond. I95, 287.

Gordon, R. E. \& MinM, J. M. (1959). A comparison of four species of Mycobacteria. J. gen. Microbiol. 2r, 736.

GraHAM, P. H. (1964). The application of computer techniques to the taxonomy of the root-nodule bacteria of legumes. J. gen. Microbiol. 35, $5 \mathrm{I}$ I.

Graham, P. H. \& Parker, C. A. (1964). Diagnostic features in the characterisation of the rootnodule bacteria of legumes. $\mathrm{Pl}$. Soil 22, 383 .

Haynes, W. C. (I95I). Pseudomonas aeruginosa-its characterisation and identification. J. gen. Microbiol. 5, 939.

Hugh, R. (1965). A comparison of Vibrio cholerae Pacini and Vibrio eltor Pribram. Int. Bull. bact. Nomen. Taxon $\mathbf{5}, 61$.

Hugh, R. \& Leifson, E. (1953). The taxonomic significance of fermentative versus oxidative metabolism of carbohydrates by various Gram-negative bacteria. J. Bact. 66, 24.

Koser, S. A. (1924). Correlation of citrate utilization by members of the colon-aerogenes group with other differentiating characteristics and with habitat. J. Bact. 9, 59.

Krieg, R. E. \& LockHART, W. R. (1966). Classification of Enterobacteria based on overall similarity. J. Bact. 92, 1275.

LANGE, R. T. (196I). Nodule bacteria associated with the indigenous Leguminosae of south-western Australia. J. gen. Microbiol. 26, 35I.

LEDERBERG, J. (I950). Isolation and characterization of biochemical mutants of bacteria. Meth. med. Res. 3, 5 .

LEIFSON, E. (I95I). Staining, shape and arrangement of bacterial flagella. J. Bact. 62, 377.

Liston, J., WiEbE, W. \& Colwell, R. R. (I963). Quantitative approach to the study of bacterial species. J. Bact. 85, I06I.

LÖHNIS, F. \& HANSEN, R. (I92 I). Nodule bacteria of leguminous plants. J. agric. Res. 20, 543.

Manual of Microbiological Methods (1957). Society of American Bacteriologists. New York: McGrawHill Book Co.

MoEller, V. (1955). Simplified test for some amino acid decarboxylases and for the arginine dihydrolase system. Acta path. microbiol. scand. 36, 158.

Paton, A. M. (1959). Enhancement of pigment production of Pseudomonas. Nature, Lond. r84, 1254.

PAton, A. M. (1960). The role of Pseudomonas in plant disease. J. appl. Bact. 23, 526.

SChroeter, J. (1886). Die Pilze Schlesiens. Cohn's Kryptogamen-Flora von Schlesien Bog. 9, I35.

Shewan, J. M., Hodgkiss, W. \& Liston, J. (1954). A method for the rapid differentiation of certain non-pathogenic asporogenous bacilli. Nature, Lond. $\mathbf{1 7 3}, 208$.

Shimwell, J. L., Carr, J. G. \& Rhodes, M. E. (I960). Differentiation of Acetomonas and Pseudomonas. J. gen. Microbiol. 23, 283.

SIERRA, G. (I957). A simple method for the detection of lipolytic activity of micro-organisms and some observations on the influence of the contact between cells and fatty substrates. Antonie van Leeuwenhoek 23, 15.

Silvestri, L., Turri, M., Hill, L. R. \& Gilardi, E. (I962). A quantitative approach to the systematics of Actinomycetes based on overall similarity. Symp. Soc. gen. Microbiol. 12, 333.

Simmons, S. S. (1926). A culture medium for differentiating organisms of the typhoid-colon aerogenes groups and for isolation of certain fungi. J. infect. Dis. 39, 209.

SNEATH, P. H. A. (1957). The application of computers to taxonomy. J. gen. Microbiol. r7, 201.

SNeAth, P. H. A. (1960). A study of the bacterial genus Chromobacterium. Iowa State J. Sci. 34, 243.

STARr, M. P. (1947). The causal agent of bacterial root and stem disease of Guayule. Phytopathology 37, 29 I.

Sokal, R. R. \& Sneath, P. H. A. (1963). Principles of Numerical Taxonomy. San Francisco. W. H. Freeman and Co.

Thornley, M. (1960) The differentiation of Pseudomonas from other Gram-negative bacteria on the basis of arginine metabolism. J. appl. Bact. 23, 37. 